\title{
Memória
}

\section{Santas anoréxicas na história do Ocidente: o caso de Santa Maria Madalena de Pazzi}

\author{
"Nos teus mandamentos estão as minhas delícias: eu os \\ amo". SI 119,47
}

A existência de transtornos alimentares em outras culturas e séculos anteriores aos relatos de Morton (1689), Gull (1868) e Lasègue $(1874)^{1}$ é de grande interesse psicopatológico, na medida em que coloca no centro da discussão a questão do patogenético e do patoplástico em psiquiatria e que torna relativa a influência da modernidade, muitas vezes colocada como fator causal principal e por vezes único.

Nesse sentido, o trabalho que Rudolph Bell (1985) desenvolveu, desde o século XIII até os dias atuais, sobre a vida de mais de 250 mulheres italianas santas e beatas da Igreja Católica, utilizando-se de escritos autobiográficos, cartas, testemunhos de confessores e relatos canônicos, pode oferecer um bom campo de discussão. ${ }^{2}$

Nascida em Florença em 2 de abril de 1566, Maria Magdalena de Pazzi conhece seu primeiro êxtase místico aos 12 anos de idade. Ingressa no convento Carmelita de Santa Maria dos Anjos em Florença, em 1582, e, quando recebe seus votos em 3 de janeiro de 1583, deixa seu nome de batismo Caterina e assume o de Maria Madalena. Em maio de 1584, adoece e, em estado de "arrebatamento", começa a ditar uma série de regras recolhidas por suas companheiras. A essas primeiras palavras, acrescentam-se outras instruções ascéticas e cartas.

Em 1585, quando ainda não completara 20 anos de idade, e dizendo-se orientada por Deus, passa a restringir sua dieta a pão e água, exceto aos domingos, quando come, sempre em pouca quantidade, apenas alguns restos de alimentos deixados na refeição pelas outras irmãs.

Forçada a se alimentar com maior quantidade por suas superioras, passa a provocar o vômito, sendo freqüentemente surpreendida comendo escondida grandes quantidades de alimento rapidamente. Para punir-se e prevenir-se das tentações diabólicas, açoita-se, dorme pouco - sempre nua sobre troncos de madeira no chão - e banha-se com água gelada em pleno inverno. Entre as tentações diabólicas que a atormentavam, figurava um intenso desejo de comer. Quando passava pela despensa, segundo seus relatos, o diabo abria as gavetas e prate- leiras, dispondo diante dela seus "tesouros culinários", seduzindo-a para interromper sua dieta de pão e água. ${ }^{2}$

“Tentadas" por um grande desejo, as modernas anoréxicas permanecem durante longo tempo paradas em frente a vitrines de confeitarias, "seduzidas" pelas guloseimas. Outras mantêm no quarto, escondidas, caixas de alimentos ou apenas suas embalagens, para que possam admirá-las por um tempo indeterminado. Além disso, o hábito de colecionar livros de receitas, folheá-los constantemente, assistir a programas culinários e cozinhar maravilhosamente as mantêm no limite de "cair em tentação".

A existência de Maria, que faleceu em 25 de maio de 1607, é um suceder de visões de crucificação, uso de coroas de espinho, sofrimentos físicos auto-impostos e longos jejuns, tudo para cumprir da maneira mais perfeita possível seu destino místico.

Sua desconsideração para com a vida e as necessidades "terrenas" pode ser confirmada em uma das frases de seus "Conselhos espirituais":

- "Que apenas Deus nos baste";

- "Recordais que estais no mundo como alguém está no exílio; assim, não há outro lugar para querer estar como em sua pátria";

A escolha do nome eclesiástico Maria Madalena, prostituta convertida na história cristã, desagradou a aristocrática família de Caterina, que lhe havia dado esse nome para homenagear Santa Caterina de Siena. Curiosamente, a adoção do nome Maria Madalena foi também uma escolha influenciada pelos escritos de Caterina de Siena, que cita Maria Madalena como um modelo para si mesma, porque, após a morte de Cristo, ela teria jejuado por 33 anos seguidos. Assim, não parece haver dúvida de que Maria Madalena de Pazzi leu os escritos de Caterina de Siena (outra suposta "santa anoréxica") e foi profundamente influenciada pelas idéias de ascetismo dessa Santa maior.

Essa influência é entendida por Eric Dingwall (Maggi, ${ }^{3}$ 1998) como uma mórbida imitação, referindo-se a Maria Madalena como uma "exibicionista masoquista". Não se sabe o que exatamente ele quer dizer, mas se pode imaginar o quanto de satis- 
fação ela obtinha diante do olhar de espanto, inveja e admiração de suas irmãs carmelitas. O certo é que essa jovem sofreu contínuas doenças, mas se dizia feliz em sofrer por Cristo: "Pati, non mori" ("padecer, Senhor, e não morrer"). ${ }^{2}$ Entretanto, alguns aspectos familiares descritos nas pacientes anoréxicas têm grande interesse psicanalítico. Maria Madalena foi filha única, perfeccionista ao extremo e conhecida como cumpridora de regras. Este, inclusive, foi o motivo que a levou a escolher o Convento das Carmelitas, onde as regras eram extremamente rígidas. Descrita como uma criança determinada e sempre elogiada por sua obediência (desde que as coisas seguissem à sua moda), recorria a crises de choro e caía doente quando impedida de seguir sua vontade. Sua mãe, como a de Caterina de Siena, era bastante autoritária, e foi com ela que Maria Madalena travou grandes batalhas até entrar para o convento e de cuja autoridade não se livrou de todo, uma vez que se deparou com Vangelista del Giocondo, uma severa e intransigente madre superiora que viria a exercer grande influência sobre ela.

O jejum auto-imposto não necessariamente significa algo da ordem de um transtorno alimentar. Sabe-se que vários povos da Antigüidade incentivavam o jejum voluntário como prática religiosa e viam na abstinência alimentar uma forma de purificação. Vandereycken (1994), ${ }^{3}$ por exemplo, aponta que, no Egito Antigo, quem quisesse ser iniciado nos mistérios de Isis e Osiris deveria ficar entre sete e 40 dias sem comer. Entre gregos e romanos, jejuava-se antes de se consultar os oráculos, e profetas do Velho Testamento jejuavam como preparação para experiências religiosas e revelações divinas. No entanto, chama a atenção o fato de a própria Igreja Católica, que em seus inícios também pregava o jejum, preocupar-se com a exagerada abstinência alimentar praticada nos mosteiros, a ponto de restringir a canonização de santas jejuadoras. ${ }^{4}$

Bynum (1987), ${ }^{5}$ estudando o contexto cultural da comida na Idade Média, argumenta que o ascetismo era uma das únicas formas de superação ou elevação espiritual da mulher, num contexto teológico em que a mulher estava para o homem assim como a carne ou corpo estão para o espírito ou alma. As- sim, as mulheres mais frágeis, mais predispostas ao pecado, menos racionais poderiam encontrar o caminho de Cristo unicamente na eucaristia ou se autoflagelando até à submissão e ao abandono do corpo. ${ }^{2}$ Hildegard de Bingen, a primeira grande teóloga do sexo feminino, escreveu no século XII: "o homem significa a divindade do filho de Deus, e a mulher, sua porção humana". ${ }^{6}$

Interpretações à parte, o clínico, tomando por base a perda de peso auto-induzida, a resistência em comer contra todos os argumentos lógicos e evidências de riscos físicos, os episódios bulímicos e o comportamento purgativo, não relutaria em dar o diagnóstico de anorexia nervosa subtipo purgativo.

Volta-se, assim, ao primeiro parágrafo: esse diagnóstico baseia-se na tradição jasperiana clássica, da divisão entre a forma imutável e o conteúdo mutante que, por sua vez, remete ao conceito platônico do eidos, o imutável.

A forma, o imutável, a essência da doença, o patogenético não respeitariam os séculos, a personalidade ou a cultura colocados no papel do patoplástico, do acessório.

Essa postura não é feita sem discussão. Dalgalarrondo, ${ }^{7}$ citando posições etnopsiquiátricas recentes, coloca em dúvida a possibilidade de adotar conceitos básicos da psiquiatria como se fossem imutáveis, universais e independentes da cultura.

Que distância então separa a caquética monja do século XVI da contemporânea anoréxica da academia de ginástica?

Táki Athanássios Cordás Ambulatório de Bulimia e Transtornos Alimentares (Ambulim) do Instituto de Psiquiatria do Hospital das Clínicas da Faculdade de Medicina da Universidade de São Paulo (IPq/HC/FMUSP); Departamento de Psiquiatria do HC/FMUSP; e Instituto de Psiquiatria do HC/FMUSP.

Cybelle Weinberg

Departamento de Fisiopatologia Experimental da FMUSP;

Ambulim; e Clínica de Estudos e Pesquisas em Psicanálise da Anorexia e Bulimia (Ceppan) do Departamento Formação em Psicanálise do Instituto Sedes Sapientiae

\section{Referências}

1. Silverman JA. History of anorexia nervosa. In: Browell KD, Fairburn CG. Eating disorders and obesity. New York: Guilford Press; 1995.

2. Bell RM. Holy anorexia. Chicago: University of Chicago Press; 1985.

3. Maggi A. Uttering the Word: the mystical performances of Maria Madalena de'Pazzi, a Renaissance visionary. New York: State University Press, 1998.

4. Vandereychen W, Ron Van Deth. From fasting saints to anorexic girls: the history of self-starvation. New York: University Press; 1994.

5. Bynum CW. Holy feast and holy fast. Londres: University of California Press; 1987.

6. Pernoud, R. Hildegard de Bingen. São Paulo: Rocco, 1996.

7. Dalgalorrondo P. Civilização e loucura - Uma introdução à História da Etnopsiquiatria, São Paulo: Lemos Ed., 1997.

8. Gosset, T. Mujeres Misticas - siglos XV-XVIII. Barcelona: José de Olañeta Editor, 1998. 